\title{
Neonatal Meningitis: How Complicated Can it be?
}

\author{
Shireen Salome Papabathini*, Upama Ghimire, Joseph Kawuki and Nathan Obore \\ Global Health School of Public Health, Southeast University, China
}

Submission: February 17, 2020 Published: March 09, 2020

*Corresponding author: Shireen Salome Papabathini, Key Laboratory of Environmental Medicine Engineering, Ministry of Education, Global Health School of Public Health, Southeast University, Nanjing, 210009, Jiangsu Province, China

\begin{abstract}
Neonatal meningitis, though uncommon, is one of the contributors to infant mortality and morbidity worldwide. It is mainly caused by group B streptococcus (GBS), Escherichia coli and other pathogens. The disease presents mild to moderate symptoms including fever, bulging fontanel, respiratory distress, among others. The disease is mainly diagnosed through cerebrospinal fluid (CSF) culture confirmation. If not timely treated, the disease may progress to devastating complications like seizures, ventriculitis, brain abscess, cerebral infarction, as well as long term neurological defects like hearing loss. Broad-spectrum antibiotics are the primary choice of treatment, depending on the type of pathogen and intrapartum antibiotic prophylaxis is vital to prevent neonatal meningitis. This review highlights the need for innovation of less invasive diagnostic tools as well as better preventive strategies like vaccination to avoid the severe complications that may ensue if treatment is not promptly initiated.
\end{abstract}

Keywords: Neonatal meningitis; Complications; Sepsis; Neonates

\section{Introduction}

Neonatal Meningitis is a severe and often life-threatening infection that involves inflammation of the membranes surrounding the brain and spinal cord and occurs during the neonatal period-the first month of life [1]. Concerning the time of diagnosis, neonatal meningitis is classified as early-onset (where clinical features appear during the first weeks of life) or late-onset meningitis (which occurs between 8-28 postnatal days) [2,3]. The disease mainly presents with signs and symptoms of sepsis including fever, respiratory distress, jaundice, irritability, and apnea, as well as bulging fontanel, refusing to feed and extreme sleepiness, among others $[4,5]$. In the United States, the incidence of neonatal meningitis is estimated to be 300 to 400 cases for every 100,000 live births. The incidence in developing countries is higher, from 0.8 to 6.1 per 1000 live births. The mortality from neonatal meningitis is estimated to be $40-58 \%$ in developing countries, and $10-15 \%$ in developed countries [6-8]. Moreover, the reporting of the disease in developing countries is suspect, and thus its burden is thought to be underestimated [9]. Neonatal meningitis is mostly caused by group B streptococcus (GBS), Escherichia coli (E. coli), and Listeria monocytogenes. Several factors underwrite the susceptibility of infants to this illness, including prematurity, postnatal age, immature immune system, gestational age, and geographic location. Although the most causes of meningitis are bacterial, some cases are due to viral and fungal infection $[4,10]$. Despite the initiation of intrapartum antibiotics in developed countries, GBS is still the most common cause of bacterial meningitis, accounting for $50 \%$ of all cases, followed by E. coli which accounts for $20 \%$. In contrast, gramnegative bacilli such as Klebsiella and E. Coli are more common than GBS in developing countries [7,11]. Meningitis caused by gram-negative bacteria often presents with more severe outcomes and complications $[10,12,13]$. The populations at highest risk include preterm infants, males, the impoverished, and daycare infants. Besides, children of mothers with a history of a sexually transmitted disease and positive GBS pregnant mothers are at risk. Mothers with Listeria infection- a foodborne illness, have a risk of passing it to their newborns [9]. Despite the high incidence and possibility of life-threatening complications, less is known about neonatal meningitis, especially by the mothers and caregivers. This review thus aims to highlight the complications of neonatal meningitis as well as its treatment and management. We used the keyword "Neonatal meningitis" to search for papers in Google 
Scholar, Web of Science and PubMed. Peer-reviewed English journal articles and case reports published about the disease were reviewed and relevant information considered.

\section{Diagnosis}

The initial clinical symptoms of neonatal meningitis are nonneurological and non-specific. They include respiratory distress or failure, poor suck, jaundice and pyrexia (temperature $>39^{\circ} \mathrm{C}$ ) $[14,15]$. In bacterial meningitis, the symptoms may often present as pale or marble skin, respiratory distress, irritability, poor feeding and hyper- or hypotonia, and in minority of cases fever (6$39 \%$ ) and seizures $(9-34 \%)$ are reported $[6,8,14]$. However, in GBS, the dominant initial signs are respiratory $(72 \%)$, cardiovascular (69\%) and neurologic (63\%) symptoms [14]. The Gold standard to confirm neonatal meningitis is Cerebrospinal fluid (CSF) culture, where CSF is preferably collected by lumbar puncture (LP) [9]. The CSF analysis must include cell count, glucose, gram stain, protein, culture and, if suspected, HSV (herpes simplex virus) polymerase chain reaction (PCR) study should be done. Positive growth of the CSF culture helps to identify the exact pathogen and refinement of treatment [16]. In CSF culture, the WBC counts range from 200 to 100,000 per $\mathrm{mL}$ and for viral meningitis range from 25 to 1000 per $\mathrm{mL}$. In comparison, there may be $80 \%$ to $100 \%$ neutrophils in bacterial illness and less than $50 \%$ in viral illness. Some studies show that even with a normal WBC count, there is the presence of meningitis [8]. PCR, C-reactive protein (CRP) and procalcitonin tests are also used for the diagnosis. PCR has a higher detection rate compared to culture ( $72 \%$ vs $48 \%$ ), is more sensitive and a real-time tool to diagnose the disease. Also, it can detect multiple pathogens, including Streptococcus pneumonia, E. coli, GBS, S. aureus and L. monocytogenes. CRP and procalcitonin are used to identify serious bacterial infection (SBI) in infants; however, the CRP results take 8-10 hours to synthesize and the sensitivity can vary. Procalcitonin test shows high sensitivity and specificity when procalcitonin is drawn in the first hours of life $[16,17]$. In bacterial meningitis, Blood cultures may be negative in $15-55 \%$ of cases, making its diagnosis difficult [17]. However, less than twothirds ratio of cerebrospinal fluid to blood glucose is indicative of the infection [18]. For all the proven and suspected cases of sepsis, a spinal tap must be done but it is controversial for seemingly healthy infants who are but at risk of sepsis from their mothers $[18,19]$. To rule out viral meningitis, all the infants born from mothers with STD's including Herpes simplex virus must be tested for viral infection. For a complete diagnosis, Liver tests, complete blood count, cerebrospinal fluid analysis, and a chest X-ray should be done [19]. Samples can be taken from the cerebrospinal fluid, skin, mouth and throat, rectum, conjunctiva (eye) and urine for viral culture and polymerase chain reaction [18].

\section{Prognosis}

Neonatal meningitis is a severe medical condition in infants that is rapidly fatal if untreated [20]. Mortality is approximately half in developing countries and ranges from $8 \%-12.5 \%$ in developed countries [10]. The mortality rate for neonatal bacterial meningitis, without treatment, advances $100 \%$. With treatment, the prognosis is determined by birth weight, pathogens and clinical severity. The mortality may be as high as $75 \%$ when the infection is due to pathogens that cause vasculitis (C. diversus, Cronobacter sakazakii (Enterobacter)) or brain abscess (Pseudomonas aeruginosa, E. coli K1, and Serratia spp) [5,21]. Prognosis is also dependent partly on the number of pathogens present in CSF at diagnosis. The persistence of positive CSF cultures correlates directly with the incidence of complications [22].

\section{Complications}

Some affected infants experience cardiorespiratory problems, such as respiratory distress syndrome or pneumonia, in association with hypotension or patent ductus arteriosus during their first days of life [23]. In addition the commonly occurring complications are mentioned below.

a) Seizures: These are involuntary jerking movement caused by abnormal electrical patterns in the brain due to various problems like altered neurochemistry due to bacterial infections. Neonatal seizures are often subtle and thus difficult to identify. They are a critical neurologic complication of infantile and childhood bacterial meningitis and are often linked with poor prognosis [21,24].

b) Hydrocephalus: Bacterial meningitis related hydrocephalus is characterized by ventricular dilation and is present in 14-65\% of infants and can occur in either the acute or the chronic phase of the disease [25].

c) Cerebral infarction (stroke): is bleeding from either the arterial or venous blood vessels in the brain. Recent evidence has established an association between stroke and bacterial meningitis in neonates [26,27].

d) Ventriculitis: This refers to inflammation of the ventricular fluid and lining of the ventricles and is sometimes associated with obstruction to cerebrospinal fluid flow. Ventriculitis is a common complication of neonatal meningitis, occurring in up to $20 \%$ of cases. It is diagnosed by neuroimaging or ventricular tap $[28,29]$.

e) Encephalomalacia: Also known as Cerebral softening is characterised by softening of brain tissues and can happen due to inflammation observed in neonatal meningitis. If not controlled promptly, it can further affect parts of the brain including the occipital lobe, frontal lobe, parietal lobe and the temporal lobe [30].

f) Subdural empyema: is intracranial collection of pus between the dura and arachnoid mater of the brain due to infections. It is only known to affect approximately $1-2 \%$ of patients with bacterial meningitis [31,32]. 
g) Brain Abscess: This is inflammation of the brain tissue caused by a collection of infected material, It may occur in 1.3$4.0 \%$ of neonates with bacterial meningitis is less common than other complication [33].

Development of the above complications may lead to long term consequences varying from moderate to severe neuro-disabilities [34]. About $20-50 \%$ of survivors may develop neurologic sequelae that include seizures, cognitive deficiencies, motor abnormalities, hearing and visual impairments [23,35,36].

\section{Prevention and Treatment}

Neonatal meningitis can be prevented mainly by intrapartum (during labour) antibiotic prophylaxis for women with current infections to reduce the risk of GBS related early-onset meningitis. For late-onset meningitis, it is mainly the role of the caretakers to stop the spread of diseases through proper hygiene [37] and proper antibiotic use. Vaccinations against Streptococcus agalactiae and E. coli could be alternative preventive methods although it is still under development [18,19]. Viral infection among neonates can only be prevented by Caesarean section delivery of the mothers showing symptoms of viral infection [38]. Broad-spectrum antibiotics are the first-line drugs and should be started as soon as possible. Ampicillin and gentamicin or cefotaxime are the antibiotic choices based on the culture results. From 8 to 28 days old, the ampicillin dose is $200 \mathrm{mg} / \mathrm{kg} /$ day divided q6 hours, plus the same dose for gentamycin or cefotaxime 150 to $200 \mathrm{mg} / \mathrm{kg}$ per day divided every 6 to 8 hours. Acyclovir is highly recommended for HSV cases and the dosage is $60 \mathrm{mg} / \mathrm{kg}$ per day divided every 8 hours, or $20 \mathrm{mg} / \mathrm{kg}$ per dose [9]. For late-onset neonatal meningitis, the anti-staphylococcal antibiotic regimen is recommended, which is aimed at sterilising the cerebrospinal fluid of all pathogens. A spinal tap must be repeated 24 to 48 hours after treatment is started to confirm sterilisation and the infants must be hospitalised until the CSF cultures are negative for 72 hours $[18,19]$.

\section{Conclusion}

This review has highlighted the burden and complications of neonatal meningitis. Knowing about these complications enables prevention and facilitates prompt treatment for neonates in the early stages of life. There is a need for consideration and innovation of less invasive methods of diagnosis since repetitive lumbar puncture is not easily acceptable by the mothers and is stressful to both parents and neonates. Besides, proper hygiene by mothers and caretakers is essential to prevent perinatal infections which predispose neonates to neonatal meningitis. Moreover, priority must be focused on better prevention strategies like vaccination.

\section{References}

1. Gaurav Gupta, Love Roa, Fawaz Al-Mufti, Sudipta Roychowdhury (2018) Neonatal Meningitis.

2. Aletayeb M, Farajzadeh S, Dehdashtian M (2010) Eleven-year study of causes of neonatal bacterial meningitis in Ahvaz, Iran. Pediatr Int 52(3): 463-466.

3. Edwards MS, Baker CJ (2004) Sepsis in the newborn. In Gershon AA, Hotez PJ, Katz SL, editors. Krugman's Infectious Diseases of Children, (11 ${ }^{\text {th }}$ edn.), Mosby, Philadelphia, USA, pp. 545-561.

4. Jean Rothman (2011) Neonatal Meningitis: Causes, Treatment, and Prevention. Everyday Health.

5. Brenda L Tesini (2018) Neonatal Bacterial Meningitis. Merck Manual.

6. Gaschignard J, Levy C, Romain O, Cohen R, Bingen E, et al. (2011) Neonatal bacterial meningitis: 444 cases in 7 years. Pediatr Infect Dis J 30(3): 212-217.

7. Furyk JS, Swann 0, Molyneux E (2011) Systematic review: neonatal meningitis in the developing world. Trop Med Int Health 16(6): 672679.

8. Ku LC, Boggess KA, Cohen-Wolkowiez M (2015) Bacterial meningitis in infants. Clin Perinatol 42(1): 29-45.

9. Lisa M Bundy, Asif Noor (2019) Neonatal Meningitis. Treasure Island (FL): StatPearls Publishing.

10. Khalessi N, Afsharkhas L (2014) Neonatal Meningitis: Risk Factors, Causes and Neurologic Complications. Iran J Child Neurol 8(4): 46-50.

11. Okike IO, Johnson AP, Henderson KL, Blackburn RM, Muller-Pebody B, et al. (2014) Incidence, etiology, and outcome of bacterial meningitis in infants aged $<90$ days in the United kingdom and Republic of Ireland: prospective, enhanced, national population-based surveillance. Clin Infect Dis 59(10): 150-157.

12. Centers for Disease Control and Prevention (2019) Bacterial meningitis.

13. Smith PB, Cotten CM, Garges HP, Tiffany KF, Lenfestey RW, et al. (2006) A comparison of neonatal Gram-negative rod and Gram-positive cocci meningitis. J Perinatol 26(2): 111-114.

14. Van de Beek D, Cabellos C, Dzupova O, Esposito S, Klein M, et al. (2016) ESCMID guideline: diagnosis and treatment of acute bacterial meningitis. Clin Microbiol Infect 22: 37-62.

15. Longe AC, Omene JA, Okolo AA (1984) Neonatal Meningitis in Nigerian Infants. Acta Paediatrica 73(4): 477-481.

16. Heath PT, Okike IO, Oeser C (2011) Neonatal meningitis: can we do better? Adv Exp Med Biol 719: 11-24.

17. Norris CM, Danis PG, Gardner TD (1999) Aseptic meningitis in the newborn and young infant. Am Fam Physician 59(10): 2761-2770.

18. Sivanandan S, Soraisham AS, Swarnam K (2011) Choice and duration of antimicrobial therapy for neonatal sepsis and meningitis. Int J Pediatr 2011.

19. Heath PT (2003) «Neonatal meningitis». Archives of Disease in Childhood: Fetal and Neonatal Edition. 88(3): 173-178.

20. Abdelmaguid N, Seleem WS, Soliman AT, Mohamed RS, Elgharbawy FM, et al. (2019) Clinical presentations, Laboratory analysis and Linear Growth in 50 Neonates and Young Infants with Acute Meningitis: One Year Experience of a Single Center in Qatar. Mediterr J Hematol Infect Dis 11(1): e2019028.

21. Chu SM, Hsu JF, Lee CW, Lien R, Huang HR, et al. (2014) Neurological complications after neonatal bacteremia: the clinical characteristics, risk factors, and outcomes. PLoS One 9(11): e105294.

22. Fouad R, Khairy M, Fathalah W, Gad T, El-Kholy B (2014) Role of clinical presentations and routine CSF analysis in the rapid diagnosis of acute bacterial meningitis in cases of negative gram stained smears. Journal of tropical medicine. 
23. Chatue Kamga HB (2016) Neuroimaging complication of neonatal meningitis in full-term and near-term newborns: a retrospective study of one center. Glob Pediatr Health 3: 2333794X16681673.

24. Chang CJ, Chang WN, Huang LT, Huang SC, Chang YC, et al. (2004). Bacterial meningitis in infants: the epidemiology, clinical features, and prognostic factors. Brain Dev 26(3): 168-175.

25. Yikilmaz A, Taylor GA (2008) Sonographic findings in bacterial meningitis in neonates and young infants. Pediatr Radiol 38(2): 129137.

26. Hernández MI, Sandoval CC, Tapia JL, Mesa T, Escobar R, et al. (2011) Stroke patterns in neonatal group B streptococcal meningitis. Pediatr Neurol 44(4): 282-288.

27. Fitzgerald KC, Golomb MR (2007) Neonatal arterial ischemic stroke and sinovenous thrombosis associated with meningitis. J Child Neurol 22(7): 818-822.

28. Kumar R, Singhi P, Dekate P, Singh M, Singhi S (2015) Meningitis Related Ventriculitis-Experience from a Tertiary Care Centre in Northern India. Indian J Pediatr 82(4): 315-320.

29. Edwards M, Baker CJ, Nordli Jr (2015) Bacterial meningites in the neonate: neurologic complications.

30. Hsu MH, Hsu JF, Kuo HC, Lai MY, Chiang MC (2018) Neurological complications in young infants with acute bacterial meningitis. Front Neurol 9: 903.
31. Hendaus MA (2013) Subdural empyema in children. Global journal of health science $5(6): 54$.

32. Liu ZH, Chen NY, Tu PH, Lee ST, Wu CT (2010) The treatment and outcome of postmeningitic subdural empyema in infants. J Neurosurg Pediatr 6(1): 38-42.

33. Feferbaum R, Diniz EM, Valente M, Giolo CR, Vieira RA, et al. (2000) Brain abscess by Citrobacter diversus in infancy: Case report. Arq Neuropsiquiatr 58: 736-740

34. Stevens JP, Eames M, Kent A, Halket S, Holt D, et al. (2003) Long term outcome of neonatal meningitis. Arch Dis Child Fetal Neonatal Ed 88(3): 179-184.

35. Theodoridou K, Vasilopoulou VA, Katsiaflaka A, Theodoridou MN, Roka $\mathrm{V}$, et al. (2013) Association of treatment for bacterial meningitis with the development of sequelae. Int J Infect Dis 17(9): 707-713.

36. Obore N, Papabathini SS, Ghimire U, Kawuki J, Musa TH. (2019) Zika Virus in Africa: Epidemiology and Determinants. J. adv. med. med. Res. 7:1-3.

37. Joseph K, Musa TH, Pherry O. (2020) Dietary practices, WASH conditions, and disease occurrence among children below five years in households of Nangabo, Wakiso district, Uganda. Scientific African.:e00291.

38. Kimberlin D. Herpes simplex virus, meningitis and encephalitis in neonates. Herpes: the journal of the IHMF. 2004 Jun;11:65A-76A..

\section{Your next submission with Juniper Publishers will reach you the below assets}

Commons Attribution 4.0 Licens

DOI: 10.19080/AJPN.2020.09.555818
- Quality Editorial service

- Swift Peer Review

- Reprints availability

- E-prints Service

- Manuscript Podcast for convenient understanding

- Global attainment for your research

- Manuscript accessibility in different formats

( Pdf, E-pub, Full Text, Audio)

- Unceasing customer service

Track the below URL for one-step submission https://juniperpublishers.com/online-submission.php 